\title{
Clinical Events Collection Date Time
}

National Cancer Institute

\section{Source}

National Cancer Institute. Clinical Events Collection Date Time. NCI Thesaurus. Code C88013.

The date and time of the clinical events data collection. 